\title{
Experimental Study of Wireless Music And Speech Communication with the Use of Technology of Single-Wire Lines
}

\author{
Valery V. Frisk \\ Department of Theory of Electrical Circuits \\ Moscow Technical University of Communications and Informatics \\ Moscow, Russia \\ frisk@mail.ru
}

\begin{abstract}
The paper presents the results of experimental studies on the wireless transmission of music and speech using the technology of single-wire lines. The ability to transmit energy, speech and music over a single-wire line allows this technology to be used to create a wireless transmission line.
\end{abstract}

Keywords: single-wire transmission line, wireless transmission line, step-up transformer, a step-down transformer, eddy current, mobile phone, microphone.

\section{INTRODUCTION}

Theoretical and experimental studies have shown the importance of developing devices based on technologies using eddy currents [1-3]. At present, another technology using single-wire power lines has received growing attention [4; 5]. An alternating electric current is propagated along a single-wire line in a vortex way [6-11].

\section{WIRELESS LINE FOR VOICE AND MUSIC}

If a closed aluminum ring is placed at the end of a single-wire line, then an alternating eddy current is formed in it. Let us establish a second analogous ring near the first ring. It produces its own eddy current. We connect an additional singlewire line to the second ring. The vortex current from the second ring will propagate through this additional one-wire line. As a result, a wireless transmission line is formed using two singlewire lines (Fig. 1).

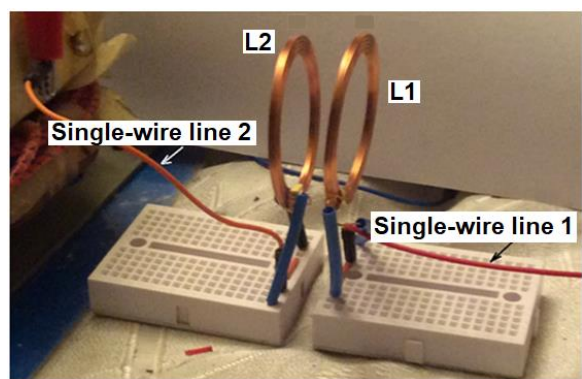

Fig.1. Wireless line for voice and music

\section{EXPERIMENTALSETUPFORTRANSFERRINGSPEEC HANDMUSICOVERAWIRELESSLINE}

The experimental method of transmitting music over a wireless line is as follows. As a music source, we use a mobile phone (Explay A350 TV) in radio mode. The electrical signal is removed from the jacks to connect the headset. We will amplify this signal using an amplifier (TDA2005R). We connect the step-up transformer $\mathrm{T} 1$ to the output of the amplifier. We connect the first single-wire line to one of the pins of the highvoltage winding of step-up transformer T1. The second terminal of the transformer winding remains free. At the end of the first one-wire line, the first closed inductor L1 is installed. Near the first coil, we establish a similar second closed inductor L2. The distance between the coils is $x=10 \mathrm{~mm}$. At the end of the second one-wire line, a step-down transformer T2 is installed. A second amplifier (TDA1562Q) is connected to the second winding of the step-down transformer T2. The BA1 speaker is connected to this amplifier. The wireless link is formed by two closed inductors L1 and L2 connected to two single-wire lines.

An experiment scheme for analyzing the transfer of music over a wireless link is shown in Figure 2.

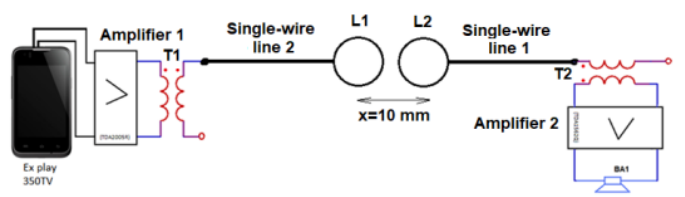

Fig. 2. Diagram for transferring speech and music over a wireless line

The operation of this wireless line is as follows. The signal is generated by the mobile phone tuned, for example, to a radio station. From the headphone outputs, the signal goes to the first amplifier, where it amplifies. The transformer-raising transformer T1 serves to excite eddy currents in a single-wire line up to the required value. As a result, in the first single-wire line, closed transverse eddy currents are excited and propagate, as was shown above. Obviously, a closed eddy current will also appear in the transmitting coil L1. This current forms an alternating magnetic field in the space near L1. In this field there is a closed receiving coil L2. A voltage arises that causes its eddy 
current. This current propagates through the second single-wire line. The second transformer T2 lowers the voltage to the required level. The second amplifier amplifies the signal to the level of the desired speaker BA1. This experiment showed that the speaker BA1 quite well reproduced the music.

\section{VOICE OVER WIRELESS WITH MICROPHONE}

The method of experimental research for the analysis of voice transmission over a wireless line is as follows., we use the microphone BM1 (Philips SBC MD150/00) instead of a mobile phone. To amplify the signal from the microphone BM1, we connect the microphone amplifier (BM137). For further amplification, the first amplifier (TDA2005R) is used. The voltage increases with the help of a step-up transformer T1. One first wire is connected to one end of the secondary winding T1. The second end of this winding remains free. The first closed inductor L1 is installed at the end of the first one-wire line. Near the first coil, we establish a similar second closed inductor L2. The distance between the coils is $x=10 \mathrm{~mm}$. A step-down transformer T2 is installed at the end of the second one-wire line. A second amplifier (TDA1562Q) is connected to the second winding of the step-down transformer T2. The BA1 speaker is connected to this amplifier. The template is designed so that author affiliations are not repeated each time for multiple authors of the same affiliation. Please keep your affiliations as succinct as possible (for example, do not differentiate among departments of the same organization). This template was designed for two affiliations.

An experimental design for the analysis of voice transmission over a wireless link is shown in Figure 3.

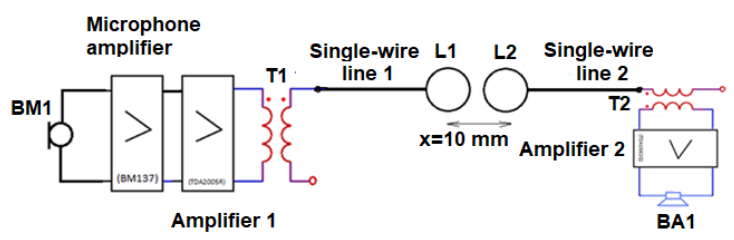

Fig. 3. Voice over wireless with microphone

This experiment showed that the speaker BA1 perfectly reproduces the speech transmitted through the microphone BM1.
As a result of this experiment, a voice signal was transmitted over the wireless line using two single-wire transmission lines.

\section{REFERENCES}

[1] Дорофеев А.Л. Вихревые токи. М.: Энергия, 1977. [Dorofeev A.L. Eddy currents. Moscow: Energy, 1977].

[2] Lammeraner J., Stafl M. Eddy Currents: Trans. from Czech. Praha, 1964.

[3] Миткевич В.Ф. Магнитный поток и его преобразования. М.; Л.: Изд-во АН СССР, 1946. 358 с. [Mitkevich V.F. Magnetic flux and its transformation. Moscow; Leningrad: Publishing House of the Academy of Sciences of the USSR, 1946].

[4] Sommerfeld A. Electrodynamik. Leipzig: Akademische Verlagsgesellschaft Oeest\&Portig K.-G, 1949.

[5] Gubo G. Surface waves and their applications to transmission lines // J. Appl. Phys. 1950. Vol. 21. P. 1119.

[6] Стребков Д.С., Некрасов А.И. Резонансные методы передачи и применения электрической энергии. М.: ГНУ ВИЭСХ, 2008. [Strebkov D.S., Nekrasov A.I. Resonant methods of transmission and application of electrical energy. Moscow: GNU VIESH, 2008].

[7] Фриск В.В. Обнаружение индукционных токов в линии связи // Нелинейный мир. 2013. №8. С. 73-75. [Frisk V.V. Detection of induction currents in the communication line // Nonlinear world. 2013. N 8. P. 73-75].

[8] Frisk V.V. Researches of electric processes in a single-wire line and in the flat condenser // T-Comm. 2014. Vol. 8, N 1. P. 58-59.

[9] Фриск В.В. Индуктивные токи в однопроводной линии связи// Материалы Международной научно-технической конференции «INTERMATIC-2012», 3-7 декабря 2013, Россия, Москва, 2012 г. М.: МИРЭА, 2012. Ч. 5. С. 199-202. [Frisk V.V. Inductive currents in a single-wire communication line // Proceedings of the International Scientific and Technical Conference "INTERMATIC2012", December 3-7, 2013, Russia, Moscow, 2012. Moscow: MIREA, 2012. Part 5. P. 199-202].

[10] Фриск В.В. Вихревые токи в однопроводной линии // Труды конференции «Телекоммуникационные и вычислительные системы», 26 ноября 2014 г. М.: Информпресс-94, 2014. С. 107109. [Frisk V.V. Eddy currents in a single-wire line // Proceedings of the conference "Telecommunication and Computational Systems”. 2014, November 2. Moscow: Informpress-94, 2014. P. 107-109].

[11] Frisk V.V. Speech transmission on a single-wire line // T-Comm. 2015. Vol. 9, N 7. P. 97-99. 